\title{
CHOROBA I ŚMIERĆ ZA MURAMI KLASZTORU PANIEN NORBERTANEK W IMBRAMOWICACH W ŚWIETLE KRONIKI ZOFII GROTHÓWNY Z LAT 1703-1741
}

Kronika Zofii Grothówny, ksieni zakonu imbramowickiego, została napisana w latach 1703-1741 i wydana drukiem w 2011 roku. Kroniki klasztorne są unikatowym dziełem pomagającym poznać życie zakonne nie tylko od strony relacji z Bogiem, podporządkowania się regułom zakonnym. Analizując te zapiski, można również dostrzec inne, bardzo istotne i ciekawe informacje. Kronika klasztoru imbramowickiego pisania przez ksienię Zofię zawiera wiele interesujących wzmianek na tematy związane z prowadzeniem klasztoru oraz jego gospodarstwem, ale można w niej znaleźć także liczne informacje odnośnie życia codziennego sióstr. Wiele miejsca kronikarka poświęca właśnie chorobom i śmierci zakonnic przebywających w klasztorze. Te dwa nieodłączne elementy życia każdego człowieka nie mogły przecież omijać zakonu kontemplacyjnego.

Jak wynika z kart kroniki, wyjazdy sióstr na leczenie poza klasztor miały miejsce dość często. Składało się na to kilka czynników. Panna przyjmowana do klasztoru, jako nowicjuszka mogła mieć problemy ze zdrowiem, do tego dochodziły z czasem trudne warunki mieszkalne w klasztorze. Nie bez znaczenia były lata, w których siostry musiały przenosić się z miejsca na miejsce po pożarze zabudowań kościelnych, by w końcu wymienić często złe, wilgotne i zimne warunki zamieszkania sióstr w nowym klasztorze. Przez dobra klasztorne przepływała rzeka Dłubnia, co jeszcze bardziej powodowało zawilgocenie powietrza i murów. W takich warunkach o chorobę nie było trudno. W konwencie imbramowickim chorowały także przebywające na naukach panny, narażone na trudne warunki bytowania w klasztorze.

Do wyjazdu sióstr poza klasztor potrzebna była zgoda przełożonej klasztoru. Z reguły jej udzielano. $Z$ wyjazdem siostry na leczenie, czy to do Krakowa czy dalej do uzdrowisk, zawsze wiązały się koszty, zwłaszcza, że mniszki imbramowickie nie podróżowały same. Zwykle wybierały się we trzy, żeby w drodze powrotnej po odwiezieniu chorej siostry do Krakowa nie wracać pojedynczo. Stąd, jeżeli panna siostra nie miała pieniędzy z posagu i ksieni również nie mogła przeznaczyć dla niej odpowiedniej kwoty posyłano po cyrulika ${ }^{1}$, by udzielił pierwszej pomocy. On również domagał się zapłaty, ale była ona mniejsza. Ksieni Grothówna zanotowała, że na jej wyjazd na Śląsk, pieniądze dali różni dobrodzieje. Był to

1 Cyrulik- wywodzi się ze zniekształconego słowa chirurg, zajmował się przede wszystkim goleniem, rwaniem zębów, ale również puszczaniem krwi i nieskomplikowanymi operacjami, często wzywany zamiast lekarza, ponieważ był o wiele tańszy, zob. B. Ogrodowska, Medycyna tradycyjna w dawnej Polsce, Warszawa 2012, s. 55-57. 
niemały koszt, ponieważ siostra wyjechała z dwiema innymi mniszkami na półtora miesiąca ${ }^{2}$. Drugi wyjazd - jak zapisała - sfinansowała ze swoich posażnych pieniędzy³. Wyjazdy na leczenie finansował także ks. Dominik Lochman.

Najczęściej odnotowane są wyjazdy na leczenie ksieni Grothówny, która, jak można wyczytać z kart Kroniki, była osobą bardzo schorowaną. Przy funkcji, jaką sprawowała w klasztorze, nastręczało to wielu problemów. Kronikarka zakonna odnotowała, że w 1722 roku, ksieni najpierw miała gorączkę trwającą dwa dni, a później spadek na nogę wielki uczuła, kiedy noga prawa bardzo opuchła i zsiniała ${ }^{4}$. Grothówna cierpiała także na „,parcie w boku prawym"5. Często zapadała na zdrowiu, trapiła ją gorączka i róża. Jednak najcięższą chorobą, która pośrednio doprowadziła do śmierci ksieni była choroba oczu. Ksieni chciała podjąć leczenie, ale nie mogła spotkać się z lekarzem, który chciał obejrzeć chorą. Czekała na niego pięć niedziel, podróżując, żeby się z nim spotkać. Puchlina, która dokuczała nodze poszła do góry, ksieni wiedziała, że umiera ${ }^{6}$.

W Kronice klasztornej niewiele można odnaleźć szczegółów dotyczących opisu chorób, na które cierpiały siostry, ale choroby trapiące zakonnice przeważnie wpisywano. I tak siostry chorowały na puchlinę 7 , bóle głowy i gardła, na co lekarstwem były ,plastry” lub „sprycowanie”, duszności i suchoty, czy gorączkę „malignę"8. Odnotowano także problemy z żołądkiem i choroby związane z nogami. Na różne dolegliwości mięśniowe czy ból smarowano ciało wódką, żeby rozgrzać miejsce choroby. Częstym lekarstwem na wszystkie dolegliwości, począwszy od bólu głowy do problemów z żołądkiem, było puszczanie krwi. Jest to odnotowane w kronice w kilku miejscach, zwykle do tego procederu wzywany był cyrulik. Przeważnie wymieniany jest pan Pączkowski. Kolejnym lekarstwem na wiele dolegliwości było stawianie baniek siekanych. Tym z kolei zajmował się wezwany przez Grothównę łaziebnik ${ }^{9}$. Do klasztoru przyjeżdżały również siostry miłosierdzia ${ }^{10}$. Siostry imbramowickie stosowały także „różne medykamenta” pochodzące z apteki krakowskiej, które wysyłali albo przełożeni klasztoru, albo komisarz. Siostra Elżbieta Górska wiele lat cierpiała na chorobę psychiczną, która siłą rzeczy musiała objawić się już po złożeniu ślubów zakonnych albowiem wiele cierpiała inkursyi ${ }^{11}$ i pokus czartowskich, tak, że czasem

\footnotetext{
Z. Grothówna, Kronika klasztorna sióstr norbertanek Imbramowicach 1703-1741, Kielce 2011, s. 126-127.

Tamże, s. 149.

Tamże, s. 152.

Tamże, s. 169.

Tamże, s. 255.

7 Puchlina- staropolska nazwa oznaczająca obrzęk, nie występuje we współczesnej medycynie. Obrzęk to gromadzenie się płynu pod skorą, przyczynami mogą być choroby wątroby, nerek, niewydolność serca czy sepsa, zob. A Szczeklik (red.), Choroby wewnętrzne, Kraków 2005, 16-17.

8 Malignus- łac. złośliwy, złośliwa gorączka, której towarzyszą majaki i halucynacje.

9 Łaziebnik- od XVIII w. wydano zakaz leczenia przez łazienników, do ich zadań należało głównie golenie i przygotowywanie kąpieli, ale mógł także stawiać bańki, zob. tamże, s. 58.

10 Siostry miłosierdzia, potocznie nazywane szarytkami- siostry mają za zadanie pomaganie chorym, przez prowadzenie szpitali, odwiedzanie chorych w domu, zbiórki pieniędzy dla potrzebujących, zob. A. Dzierżak, S. Motyka, W. Bomba, J. Dukała, Zgromadzenie Sióstr Miłosierdzia św. Wincentego a Paulo w Polsce (1652-2002), Kraków 2002, s. 9-18.

11 Incursio (łac.)- napad
} 
i przeciwko samemu bluźnieła Bogu $u^{12}$. Tuż przed śmiercią zdołała przyjąć sakramenty namaszczenia, odzyskawszy w tym krytycznym momencie świadomość umysłu ${ }^{13}$.

Do Krakowa zakonnice udawały się przede wszystkim dla podratowania zdrowia do norbertańskiego klasztoru zwierzynieckiego i do klasztoru bernardynek p.w. św. Józefa oraz do konwentu panien klarysek p.w. św. Andrzeja. Wizyty takie trwały bardzo różnie. Wszystko zależało od stanu zdrowia siostry, jednak najczęściej nie przekraczały miesiąca. Siostry, przebywając w Krakowie, miały na miejscu opiekę lekarza i cyrulika, którzy do Imbramowic nie zawsze mieli czas. by dojechać i przebywali w nich zazwyczaj krótko, kilka godzin, z uwagi na innych chorych.

Ksieni Grothówna sama udawała się kilkakrotnie do „wód landeckich”, czyli do dzisiejszego Lądka-Zdroju na Śląsku oraz do „wód krzeszowskich” w okolice Rudawy (która wówczas należała do ks. Lochmana) na kąpiele uzdrowiskowe z dwoma innymi siostrami. Wyjazdy ksieni trwały od dwóch tygodni do dwóch miesięcy. Z kolei siostra Modrzewska dostała pozwolenie na wyjazd dla podratowania zdrowia do krewnych na Pogórze ${ }^{14}$.

Decyzję o wezwaniu lekarza, cyrulika, czy o wyjeździe podejmowano na podstawie stanu zdrowia siostry. Kiedy siostra Lewikowska zachorowała na puchlinę [...] sprowadziło się infirmaryi dla lepszej wygody. Zaraz tegoż dnia opatrzyla się sakramentami świętemi, czekając woli Boskiej, co z nią dalej się będzie się działo ${ }^{15}$. Posłano po doktora, który przybył po kilku dniach, ale widocznie jej stan był ciężki, bo zmarła dziesięć tygodni później w szpitalu zakonnym ${ }^{16}$. Zdarzały się przypadki bardzo krytyczne, siostra Pajęcka [...]mając kolano bardzo szkodliwie uroste, wycierpiała nieznośna mękę, gdy jej go cyrulicy rżnęli[... ${ }^{17}$. Inna siostra -Anna Gołębiowska- po upadku ze schodów stłukła tak nogę, że potrzebna była pomoc cyrulika. Do siostry Magdaleny Zaleskiej również musiał przyjechać z tego powodu, że chorowała na nogę, bo sie jej dziury porobity ${ }^{18}$.

A zatem stan zdrowia sióstr i zapewne ich kłopoty z układem kostnym miały podłoże reumatologiczne, co było $\mathrm{m}$. in. konsekwencją zimnych i wilgotnych pomieszczeń.

Choroba i śmierć jako nieodłączny element życia każdego człowieka, została zapisana również na kartach Kroniki. Na kolejnych jej stronach można odczytać dramatyczne opisy agonii sióstr, np. siostry Śliwskiej, która na chórze, podczas modlitwy paraliżem zrażona $i$ zaraz jej odjeno mowę, wzrok $i$ stuch, tak że żadnego zmystu nie miała, a tylko oddychała, a jedna ręka ruszała ${ }^{19}$. Mimo interwencji lekarza siostra zmarła po trzech dniach w bólu ${ }^{20}$. Siostra Zofia Żuchowska zmarła po czternastu tygodniach ciężkiej choroby. Doszło nawet do tego, że ciało jej przed śmiercia robacy toczeli ${ }^{21}$. Inna siostra, Katarzyna Suleńska, niewidoma przez 10 lat zamknęła się w celi na noc. Rano, kiedy nie zeszła na modlitwę ani się na kołatanie do jej celi nie odzywała, zamkiem dojrzawszy leżący w tóżku, kazałam [ksieni]

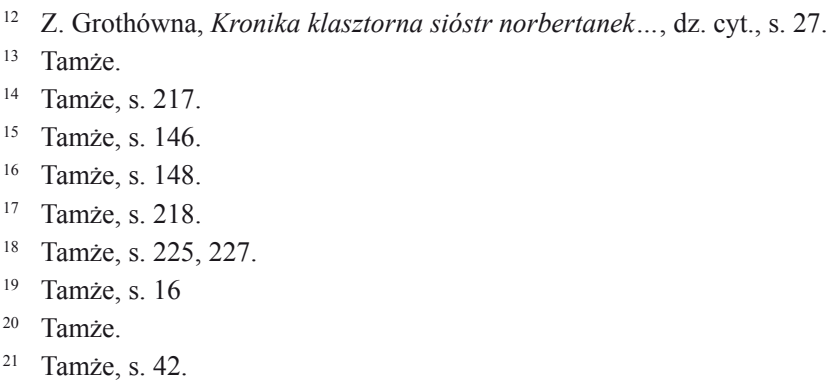


drabine do okna przystawić $i$ wniść ${ }^{22}$. Mniszka żyła jeszcze, ale nie dało się już nic zrobić, po trzech godzinach umarła ${ }^{23}$.

Równie dramatyczna i pełna bólu była śmierć ksieni Zofii Grothówny. Ból w nodze musiał być bardzo dokuczliwy, gdyż przeczuwała, że umiera. Uzyskała sakrament namaszczenia chorych i zmarła. Pogrzeb, mimo iż ksieni przebywała w chwili śmierci w Kazimierzy Małej, odbył się po trzech dniach. Ciała nie wystawiano długo ze względu na panujący upał. W Kazimierzy odprawiono mszę żałobną, a siostry imbramowickie śpiewały wigilje. W dzień pogrzebu odprawiono dwie msze śpiewane, obecnych było wielu księży i zakonników oraz około 50 ubogich, których częstowano zwyczajowo jedzeniem. Nadto rozesłano jałmużnę dla najuboższych do klasztorów w Krakowie. Trzynaście dni po śmierci ksieni odprawiono ponownie egzekwie. Jak zapisano- sprawiono Grothównie nową trumnę [...]biało obita stała na trzech gradusach, także biało obitych. Około trumny stało dwanaście świec wielkich... sześć pochodni trzymano, a za wielkim ołtarzem między innemi świecami, sześć pochodni gorzało. Przy trumnie klęczało nas zakonnic trzynaście ze świecami, któreśmy od nieboszczki dobrodziejki przyjęte były do habitu zakonnego[...]. Na pogrzebie ksieni była ogromna liczba (90!) zebranych na egzekwiach kapłanów. Mszy przewodniczył opat norbertanów z Nowego Sącza, przełożony cyrkarii polskiej. Zakonnice wydały obiad dla 300 ubogich wiernych. Msze święte za zmarłą ksienię odbyły się jeszcze 15. i 40. dnia po jej śmierci ${ }^{24}$.

Pogrzeb odprawiano zazwyczaj w przeciągu trzech dni od śmierci ${ }^{25}$. Na pogrzeby panien chórowych czy konwersek przyjeżdżało zwykle kilku księży i zakonników z różnych klasztorów. Odprawiano mszę za zmarłą w kościele nad grobem, bowiem siostry były chowane w krypcie znajdującej się w kościele wybudowanym za przełożeństwa ksieni Grothówny, a nawet w trakcie jego budowy, czyli od 1712 roku. Trudno jednoznacznie stwierdzić, czy przy wszystkich pogrzebach była obecna kapela. W Kronice można odnaleźć tylko jeden taki zapis na pogrzebie Anny Postupalskiej.

Na kartach Kroniki ksieni Grothówna zapisała niezwykłą uroczystość, pochówek byłej przełożonej. Siostra Krystyna Oraczowska, była ksieni imbramowicka, przebywała po pożarze w konwencie zwierzynieckim. Nie wracała do Imbramowic z powodu szczupłych środków materialnych konwentu i swojej choroby, tam też zmarła 11 października 1712 roku. Ksieni Grothówna zanotowała w Kronice szczegółowo obrzędy pochówkowe. Jeszcze w klasztorze na Zwierzyńcu odprawiono nabożeństwo, bowiem mniszki z podkrakowskiego konwentu chciały pochować byłą ksienię u siebie. Siostra Oraczowska była przełożoną w klasztorze imbramowickim. Dlatego też zakonnice, a nade wszystko Zofia Grothówna, domagały się, żeby sprowadzono ciało zmarłej. Wywiązał się niemały konflikt. Konwent w Imbramowicach miał pierwszeństwo. To tam Krystyna Oraczowska piastowała przecież najwyższą funkcję w klasztorze, dlatego ks. Dominik Lochman domagał się wydania ciała. Zakonnice zwierzynieckie chyba do końca były przekonane, że ciało nieboszczki spocznie w ich klasztorze, bowiem po odbytych tam obrządkach pogrzebowych został otwarty nawet grób, ale dzięki usilnym staraniom ks. Lochmana po ceremonii trumnę wyniesiono i przetransportowano

\footnotetext{
22 Tamże, s. 105.

23 Tamże.

24 Tamże, s. 255-256.

25 Tylko Anna Postupalska została pochowana osiem dni po śmierci, nie podano przyczyny tego procederu, zob. tamże, s. 255.
} 
do Imbramowic. Księża jechali obok trumny. Po drodze, która prowadziła przez Skałę. Biły uroczyście dzwony, także po przyjeździe do Imbramowic w kościele farnym p. w. św. Benedykta Opata. Okoliczna ludność zbierała się systematycznie wokół konduktu, by wziąć udział w ostatniej drodze byłej ksieni imbramowickiej. Potym kilku księży wyszło na droge $i$ ciało złożywszy na mary ${ }^{26}$, kondukt odśpiewano z prcoesyja i złożono ciało $w$ kościele ${ }^{27}$. Nazajutrz odprawiono kilka mszy świętych za nieboszczkę śpiewanych choratem. Łącznie przyjechało 30 kapłanów i zakonników z Hebdowa. Potem prałat ubrany w kapę, zakonnicy i okoliczny lud odprowadzali zmarłą do kaplicy. Siostry norbertanki imbramowickie uroczyście wyszły im naprzeciw, ustawiając się po obu stronach furty ze świecami ${ }^{28}$. Mniszki przejęły trumnę od księży i zaniosły ją do drewnianej kapliczki. Siostra Oraczowska zmarła dwa lata po całkowitym zniszczeniu zabudowań konwentualnych. Zakonnice przyozdobiły kapliczkę czarnym suknem i świecami, katafalk stanął w centrum pomieszczenia. [...]potym posztyśmy wedtug zwyczaju pogrzebowego komendę śpiewana odprawić, po który była msza święta śpiewna, która siostry choratem śpiewały. Po skończony mszy zaczęli księża wilie ${ }^{29}$ śpiewać. Potym suma była solenna z stacjami,.. po który skończeniu zaczeni kondukt, a myśmy znowu wyszly po ciało ze świecami do kaplice $i$ wziawszy trumnę zaprowadzityśmy do kościoła nad grób[...]. Po ostatnich ceremoniach nad grobem siostry Oraczowskiej, ksieni Grothówna wydała dla wszystkich przybyłych, zarówno księży jak i ludu, obiad. Cały pogrzeb opłacał konwent imbramowicki ${ }^{30}$.

Po zakończonych ceremoniach pogrzebowych częstym zwyczajem było zapraszanie ubogich na posiłek i rozdawnictwo jałmużny. Tak też uczyniła przełożona imbramowicka po śmierci Krystyny Oraczowskiej dla ratowania jej duszy sprowadziła do konwentu 24 ubogich, którzy po wysłuchaniu mszy mogli posilić się na dziedzińcu zakonnym, a następnie otrzymali jałmużnę. Był też zwyczaj w dzień po śmierci odprawiania przez siostry wilji $i$ komend śpiewanych ${ }^{31}$. Również trzydziestego dnia po śmierci, według zwyczaju zakonnego, odprawiły się wilije z komenda i msza śpiewana oraz obiad dla ubogich, których tym razem było aż $46^{32}$. Nadto za siostry zmarłe w konwencie odprawiano msze święte rok po śmierci.

Trudno jest określić, w jakim wieku umierały zakonnice. Przy większości nie zanotowano bowiem lat, ale zdarzało się, że kronikarka zapisywała wiek zmarłej. Z danych w Kronice można odczytać, że najstarszą zmarłą siostrą była przeorysza Franciszka Siemieńska która miała lat wieku swego 82, w zakonie przebywała 68 lat(!). Siostra Barbara Dębińska miała w chwili śmierci około 80 lat, mniszka Katarzyna Suleńska zmarła w wieku lat 70, w klasztorze była przez 52. Krystyna Rapstyńska miała z kolei 54 lata, Katarzyna Misiowska również zmarła, mając 54 lat, a ksieni odnotowała również, że zakonnicą była przez okres 30 lat.

\footnotetext{
26 Mary- nosidła, na których niesiono zmarłego do grobu, Z. Gloger, Encyklopedia staropolska, t. 3, Warszawa 1989, s. 191.

27 Z. Grothówna, Kronika klasztorna sióstr norbertanek..., dz. cyt. 60.

28 Po spaleniu zabudowań zakonnic formalnie nie obowiązywała reguła, więc mogły bez pozwoleń wyjść przed furtę.

29 Wilie (łac.) - czuwanie.

30 Z. Grothówna, Kronika klasztorna sióstr norbertanek..., dz. cyt., s. 59-61.

31 Tamże.

32 Tamże, s. 62.
} 
O Konstancji Lisińskiej zanotowano tylko informację, że w zakonie żyła lat $45^{33}$, a zatem musiała mieć co najmniej około 60 lat.

Księża spowiednicy, którzy zmarli w konwencie imbramowickim byli chowani również w kościele. Odnotowane są także przypadki śmierci osób świeckich w klasztorze. Jedną z takich była przebywająca tam na stołownicy rozwódka pani Teresa Kamodzińska, której krewni darowali konwentowi trzy tysiące ze wsi Raszków (dawny powiat włoszczowski) w zamian za odprawienie mszy w intencji nieboszczki w niektóre wtorki i piątki. Nadto mniszki miały w każdy piątek po jutrzni modlić się słowami: Qui passus es pro nobis. Jesu Christe misere nobis ${ }^{34}$. Pochowano także dobrodziejkę zakonu Agnieszkę Zakrzewską ze Ściborzyc, której ciało zostało złożone w tym samym miejscu w kościele gdzie zakonnice ${ }^{35}$. W klasztorze złożono również ciało uczennicy Katarzyny Grothówny, która, po zakończeniu nauki w klasztorze, powróciła do swoich rodziców, ale w pięć tygodni później rozchorowała się i zmarła na ospę ${ }^{36}$. Ostatnią świecką pochowaną w klasztorze za rządów ksieni Grothówny była Anna Grothówna, mająca 70 lat żyjąc ustawicznie w postach i umartwieniach. Przełożona sprawiła pogrzeb z pieniędzy zakonnych, zapraszając i goszcząc 15 ubogich, aby zadośćuczynienie grzechom zmarłej ${ }^{37}$.

Na kartach Kroniki można odnaleźć również informację o pogrzebie serca starościny nakielskiej Doroty Gębickiej z domu Grothówny w 1733 roku. Po trzech dniach od śmierci jej ciało zostało złożone w kościele reformatów w Krakowie, natomiast serce spoczęło w specjalnym marmurowym nagrobku przy ołtarzu Najświętszej Marii Panny. Przy tej okazji rodzina zmarłej ofiarowała zakonowi zapas świec na trzy lata i dużo tkanin żałobnych ${ }^{38}$. O innym niezwykłym wydarzeniu zanotowanym na kartach Kroniki można się dowiedzieć już pod jej koniec. Otóż po spaleniu kościoła farnego w 1732 roku i po jego odbudowie cztery lata później, odbył się pogrzeb kości. Była to raczej skromna uroczystość połączona z konsekracją nowego kościoła ${ }^{39}$. A zatem najprawdopodobniej był to „powtórny” pochówek i złożenie kości w tzw. ossuarium.

W Kronice można znaleźć także opisy zgonów okolicznych chłopów lub majstrów pracujących przy odbudowie klasztoru. I tak ksieni odnotowała śmierć komornika z Zagórowy, który kopał glinę na cegłę. Nieszczęśliwym trafem ziemia osunęła się, a jego przysypało całkowicie. Przełożona sprawiła mu pogrzeb za pieniądze klasztorne i pochowała w farze ${ }^{40}$. Przy budowie kościoła i klasztoru zginęło trzech murarzy. Ksieni każdemu sprawiła pogrzeb i pochowała w farze.

Msze święte za zmarłych odprawiano również w intencjach dobrodziejów i przełożonych zakonu. Tak jak na przykład za kanonika krakowskiego Marcina Węgrzynowicza ${ }^{41}$ i An-

33 Tamże, strony po kolei 89, 26, 104, 28, 85, 227.

34 Tłumaczenie: Ten, który poniósł za nas śmierć, Jezu Chryste zmiłuj się nad nami; Z. Grothówna, Kronika klasztorna sióstr norbertanek..., dz. cyt., s. 28.

35 Tamże, s. 131.

36 Tamże, s. 109.

37 Tamże, s. 245.

38 Tamże, s. 236.

39 Tamże, s. 242.

40 Tamże, s. 67.

${ }^{41}$ Ks. Marcin Wegrzynowicz- kanonik krakowski, kustosz kielecki, kanonik płocki, archidiakon Pilecki, proboszcz w Tczycy, L. Łętowski, Katalog biskupów, prałatów i kanoników krakowskich, t. 4, Kraków 1853, s. 213. 
drzeja Węgrzynowicza ${ }^{42}$, biskupa krakowskiego Łubieńskiego czy architekta zabudowań konwentu Kacpra Bażankę. W rok po śmierci Agnieszki Zakrzewskiej odprawiono dwie msze za nieboszczkę ${ }^{43}$. Ksieni Grothówna modliła się także razem z całym konwentem za swoją siostrę Anielę Grothównę, bernardynkę w klasztorze krakowskim u św. Józefa ${ }^{44}$.

Tabela 1 Siostry zakonne przebywające w Klasztorze imbramowickim za przełożeństwa ksieni Zofii Grothówny 1703-1741.

\begin{tabular}{|c|c|c|c|c|}
\hline Siostra & Nowicjat & Profesja & Funkcja w klasztorze & Data śmierci \\
\hline $\begin{array}{l}\text { Franciszka } \\
\text { Siemieńska }\end{array}$ & 1652 & 1653 & $\begin{array}{c}\text { Siostra chórowa/ } \\
\text { przeorysza }\end{array}$ & 24 kwietnia 1716 \\
\hline $\begin{array}{c}\text { Krystyna } \\
\text { Oraczowska }^{45}\end{array}$ & 1653 & 1654 & $\begin{array}{c}\text { Siostra chórowa/ksieni } \\
1688-1703\end{array}$ & 11 października 1712 \\
\hline $\begin{array}{l}\text { Katarzyna } \\
\text { Suleńska }^{46} \\
\end{array}$ & 1653 & 1654 & $\begin{array}{c}\text { Siostra chórowa/ } \\
\text { kantorka }\end{array}$ & 4 sierpnia 1717 \\
\hline Barbara Dembińska & 1663 & 1664 & Konwerska & 4 kwietnia 1707 \\
\hline $\begin{array}{c}\text { Krystyna } \\
\text { Rabsztyńska }\end{array}$ & 1674 & 1676 & $\begin{array}{l}\text { Siostra chórowa/ } \\
\text { cerkatorka }\end{array}$ & 20 lipca 1707 \\
\hline $\begin{array}{l}\text { Elżbieta Aleksan- } \\
\text { dra Górska }\end{array}$ & 1674 & 1676 & Siostra chórowa & 14 maja 1707 \\
\hline $\begin{array}{l}\text { Helena Magdalena } \\
\text { Lewikowska }\end{array}$ & 1678 & 1680 & $\begin{array}{l}\text { Siostra chórowa/ } \\
\text { mistrzyni panien } \\
\text { świeckich }\end{array}$ & 22 czerwca 1722 \\
\hline $\begin{array}{l}\text { Agnieszka Helena } \\
\text { Słomińska }\end{array}$ & 1678 & 1681 & $\begin{array}{l}\text { Siostra chórowa/ } \\
\text { zakrystianka }\end{array}$ & 9 marca 1743 \\
\hline Jadwiga Śliwska & 1685 & 1687 & $\begin{array}{l}\text { Siostra chórowa/ mi- } \\
\text { strzyni nowicjatu }\end{array}$ & 12 grudnia 1705 \\
\hline $\begin{array}{l}\text { Konstancja Lud- } \\
\text { miła Lisińska }\end{array}$ & 1685 & 1687 & $\begin{array}{l}\text { Siostra chórowa/ sza- } \\
\text { farka, furtianka }\end{array}$ & 23 marca 1730 \\
\hline $\begin{array}{c}\text { Katarzyna } \\
\text { Misiowska }^{47}\end{array}$ & 1687 & 1688 & Siostra chórowa & 21 stycznia 1716 \\
\hline $\begin{array}{c}\text { Zofia Magdalena } \\
\text { Krajowska }\end{array}$ & 1688 & 1691 & Siostra chórowa & 17 kwietna 1729 \\
\hline $\begin{array}{c}\text { Marianna } \\
\text { Modrzejowska }^{48}\end{array}$ & 1690 & 1692 & $\begin{array}{l}\text { Siostra chórowa/ se- } \\
\text { kretarka, przeorysza }\end{array}$ & 23 listopada 1745 \\
\hline Zofia Żuchowska & 1690 & 1692 & Siostra chórowa & 15 maja 1710 \\
\hline
\end{tabular}

42 Ks. Andrzej Węgrzynowicz- doktor obojga praw, kanonik prebendy Kunice, kustosz sandomierski, kanonik krakowski, kielecki, zmarł w 1727 roku, L. Łętowski, Katalog biskupów, prałatów i kanoników krakowskich, dz. cyt., s. 213.

43 Z. Grothówna, Kronika klasztorna sióstr norbertanek..., dz. cyt., s. 141.

44 Siostra Aniela (Marianna) Grothówna- bernardynka z klasztoru św. Józefa w Krakowie, nowicjat 1701, w 1723 była w Imbramowicach, zmarła 1.05.1727, M. Borkowska, Leksykon zakonnic polskich epoki przedrozbiorowej, Polska Centralna i Poludniowa, t. 2, Warszawa 2005, s. 219.

45 W Kronice również Oraczowski.

46 W Kronice także Sulińska.

47 W Kronice przemiennie z Misiowski.

48 W Kronice również Modrzejowski. 


\begin{tabular}{|c|c|c|c|c|}
\hline Teresa Majerówna & 1691 & 1692 & $\begin{array}{c}\text { Siostra chórowa/ } \\
\text { podkantorka }\end{array}$ & $\begin{array}{c}6 \text { października } 1765 \\
\text { (miała 105 lat) }\end{array}$ \\
\hline Zofia Grothówna & 1691 & 1694 & Siostra chórowa/ ksieni & 31 maja 1741 \\
\hline Anna Gołębiowska & 1693 & $?$ & $\begin{array}{c}\text { Siostra chórowa/ refek- } \\
\text { tarka, przeorysza }\end{array}$ & $\begin{array}{c}13 \text { października(?) } \\
1741 \\
\end{array}$ \\
\hline Teresa Reklowska $^{49}$ & 1698 & 1699 & $\begin{array}{c}\text { Siostra chórowa/ infir- } \\
\text { merka, cyrkatorka }\end{array}$ & 28 grudnia 1746 \\
\hline $\begin{array}{c}\text { Anna Katarzyna } \\
\text { Rodecka }\end{array}$ & 1698 & 1699 & $\begin{array}{l}\text { Siostra chórowa/ } \\
\text { furtianka }\end{array}$ & 26 kwietnia 1746 \\
\hline Anna Postupalska & 26 lipca 1707 & 1709 & $\begin{array}{c}\text { Siostra chórowa/ } \\
\text { kantorka i mistrzyni } \\
\text { duchowa }\end{array}$ & 11 maja 1741 \\
\hline Jadwiga Majerówna & $\begin{array}{l}13 \text { paździer- } \\
\text { nika } 1707\end{array}$ & 1709 & $\begin{array}{c}\text { Siostra chórowa/ } \\
\text { podkantorka }\end{array}$ & 1 marca 1767 \\
\hline Zofia Stoińska ${ }^{50}$ & 1709 & $\begin{array}{c}21 \text { maja } 1710- \\
\text { rezygnacja }\end{array}$ & Siostra chórowa & - \\
\hline Justyna Otfinowska & - & - & Probantka & 29 marca 1711 \\
\hline Anna Kochanowska & $\begin{array}{l}29 \text { sierpnia } \\
1717\end{array}$ & $\begin{array}{l}3 \text { września } \\
1718\end{array}$ & $\begin{array}{l}\text { Siostra chórowa/ } \\
\text { mistrzyni panien } \\
\text { świeckich }\end{array}$ & 23 listopada 1761 \\
\hline Teresa Wietrzyńska & $\begin{array}{c}29 \text { sierpnia } \\
1717 \\
\end{array}$ & $\begin{array}{c}29 \text { stycznia } \\
1719 \\
\end{array}$ & $\begin{array}{c}\text { Konwerska/ Siostra } \\
\text { chórowa }\end{array}$ & 10 stycznia 1765 \\
\hline Teresa Zagrodzka & $\begin{array}{c}29 \text { sierpnia } \\
1717 \\
\end{array}$ & $\begin{array}{c}29 \text { stycznia } \\
1719\end{array}$ & Konwerska & 1 czerwca 1747 \\
\hline $\begin{array}{c}\text { Weronika } \\
\text { Fazerówna }\end{array}$ & $\begin{array}{c}3 \text { września } \\
1718 \\
\end{array}$ & $\begin{array}{c}29 \text { paździer- } \\
\text { nika } 1719 \\
\end{array}$ & $\begin{array}{c}\text { Siostra chórowa/ } \\
\text { piwniczna }\end{array}$ & 9 grudnia 1755 \\
\hline Anna Pajęcka ${ }^{51}$ & \begin{tabular}{|c|}
28 stycznia \\
1720 \\
\end{tabular} & $\begin{array}{c}16 \text { lutego } \\
1721 \\
\end{array}$ & $\begin{array}{c}\text { Siostra chórowa/ } \\
\text { infirmerka }\end{array}$ & 26 sierpnia 771 \\
\hline Barbara Grothówna & \begin{tabular}{|c|}
28 stycznia \\
1720 \\
\end{tabular} & $\begin{array}{c}16 \text { lutego } \\
1721 \\
\end{array}$ & $\begin{array}{c}\text { Siostra chórowa/ } \\
\text { refektarka }\end{array}$ & 8 października 1749 \\
\hline $\begin{array}{c}\text { Magdalena } \\
\text { Zalejska }^{52}\end{array}$ & $\begin{array}{c}7 \text { sierpnia } \\
1720 \\
\end{array}$ & $\begin{array}{c}7 \text { sierpnia } \\
1721 \\
\end{array}$ & $\begin{array}{c}\text { Siostra chórowa/ } \\
\text { szafarka }\end{array}$ & 7 maja 1737 \\
\hline $\begin{array}{c}\text { Katarzyna } \\
\text { Bąkowska }^{53}\end{array}$ & ja 1723 & $\begin{array}{c}9 \text { kwietnia } \\
1725\end{array}$ & $\begin{array}{l}\text { Siostra chórowa/ } \\
\text { podzakrystianka }\end{array}$ & 2 maja 1758 \\
\hline $\begin{array}{c}\text { Teresa Anna } \\
\text { Miroszewska }^{54} \\
\end{array}$ & \begin{tabular}{|c|}
25 listopada \\
1525 \\
\end{tabular} & $\begin{array}{c}30 \text { marca } \\
1727 \\
\end{array}$ & Siostra chórowa & 2 lipca 1769 \\
\hline Salomea Bogucka ${ }^{55}$ & \begin{tabular}{|c|}
11 czerwca \\
1726 \\
\end{tabular} & $\begin{array}{c}24 \text { czerwca } \\
1728 \\
\end{array}$ & Siostra chórowa & 12 grudnia 1767 \\
\hline $\begin{array}{c}\text { Teresa } \\
\text { Chwalibożanka }\end{array}$ & \begin{tabular}{|c|}
25 paździer- \\
nika 1727 \\
\end{tabular} & $\begin{array}{c}21 \text { listopada } \\
1729 \\
\end{array}$ & Siostra chórowa & 17 grudnia 1788 \\
\hline
\end{tabular}

\footnotetext{
49 W Kronice na przemian z Rychlowska.

50 W Kronice również Stroińska.

51 W Kronice na przemian z drugą pisownią: Pajęcki.

52 W Kronice także Zaleska.

53 W Kronice przemiennie Bąkowski.

54 W Kronice również Miraszewska.

55 W Kronice na przemian z Bogucki.
} 


\begin{tabular}{|c|c|c|c|c|}
\hline Józefa Urbańska & 5 lutego 1730 & 4 marca 1731 & Siostra chórowa & 11 kwietnia 1790 \\
\hline Helena Łękawska & 7 lutego 1738 & 1739 & Siostra chórowa & 1 czerwca 1778 \\
\hline $\begin{array}{c}\text { Katarzyna } \\
\text { Nakielska }\end{array}$ & 1739 & $\begin{array}{c}30 \text { paździer- } \\
\text { nika } 1740\end{array}$ & Siostra chórowa & 9 czerwca 1775 \\
\hline Elżbieta Tokarska ${ }^{12}$ & $\begin{array}{c}1 \text { czerwca } \\
1740\end{array}$ & 1741 & Siostra chórowa & 6 lipca 1764 \\
\hline $\begin{array}{l}\text { Katarzyna } \\
\text { Grothówna }\end{array}$ & 6 lipca 1740 & 1741 & Siostra chórowa & 17 lutego 1758 \\
\hline $\begin{array}{c}\text { Agnieszka Feli- } \\
\text { cjanna Otwinowska }\end{array}$ & $\begin{array}{c}25 \text { sierpnia } \\
1741\end{array}$ & 1742 & Siostra chórowa & 30 lipca 1785 \\
\hline
\end{tabular}

Tabela przedstawia zakonnice przebywające w klasztorze imbramowickim $\mathrm{w}$ latach 1703-1741. Łącznie za przełożeństwa ksieni Grothówny przebywało w klasztorze 40 sióstr zakonnych. Jeżeli panna pochodziła ze stanu szlacheckiego, zostawała panną chórową, jeżeli nie - konwerską. Siostry chórowe sprawowały wyższe stanowiska w hierarchii klasztornej. W Imbramowicach większość panien zakonnych pochodziło z rodzin szlacheckich. W jednym przypadku ksieni Grtothówna mianowała Teresę Wietrzyńską na siostrę chórową, za jej zasługi i ciężką pracę w klasztorze. Panny wstępowały do klasztoru w różnym wieku, zazwyczaj do 21 roku życia. Jednak na podstawie Kroniki z lat 1703-1741 nie ma możliwości ustalenia dokładnego przedziału wiekowego. Po wstąpieniu do nowicjatu panny siostry przygotowywały się do ślubów wieczystych około dwóch lat. Później, sprawując przydzielone przez ksienię funkcje, wiodły życie w zaciszu klasztornym. W klasztorze najkrócej, bo 17 lat, przebywała siostra Magdalena Zalejska, natomiast najdłużej Teresa Majerówna -74 lat (zmarła mając 105 lat). Średnia wieku zakonnic przebywających w Imbramowicach w latach $1703-1741$ to 42 lata. ${ }^{56}$

\section{Illness and death behind the walls of the convent of the Norbertine in Ibramowice in the light of the Chronicles of Sophia Grothówna from the years 1703-1741 Summary}

The article describes illness and death behind the walls of the convent of the Norbertine in Ibramowice in light of The Chronicle Sophia Grothówna from the years 1703-1741. Health problems and death in human life are two inevitable events. As a people we know this is unavoidable and we will meet every existence. Sisters of Mary also were afflicted with minor or major health problems. The nuns lived in damp conditions. At the monastery Imbramowice flows flows the river Dłubnia, causing a humid environment. Nuns in Imbramowice had to contend with difficult housing conditions after a fire in 1710. Norbertine's coped with the diseases in various ways:leaving for treatment to spas (with the consent of the bishop and the abbess), or waiting for assistance of a barber, doctors came less frequently. The article contains also diseases to which the sisters suffered. In the second part, the paper describes the death of sisters and everything that is associated with it. Every act of dying featured in the pages of The Chronicle abbes Grothówna was dramatic. After the death of a Norbertine followed by a funeral, if the nun exercised a high function at the monastery burial was very solemn and distinguished guests arrived. The Sisters of Mary also organized refreshments for the poor people, to help the dead and prayed for a specified period of time. The article

56 W Kronice także Tokarski. 
includes a list of all the sisters residing at the monastery in Imbramowice over the years 1703-1741. The table presents information: date of commencement of the novitiate, professed, perpetual function each nun and date of death.

Keywords: The monastery, Norbertine, Imbramowice, nuns, death, illness

Nota o Autorze: Milena Mierzejewska w latach 2009-2014 była studentką Uniwersytetu Kardynała Stefana Wyszyńskiego w Warszawie na kierunku historia. Obecnie jest doktorantką na tejże uczelni. Swoje studia doktoranckie rozpoczęła w 2014 roku. Przedmiotem jej zainteresowania jest Historia Kościoła, a przede wszystkim historia zakonów żeńskich klauzurowych. Swoje badania prowadzi na przykładzie benedyktynek Sierpeckich, a wcześniej norbertanek imbramowickich. 